Supplement of

\title{
Age and driving mechanisms of the Eocene-Oligocene transition from astronomical tuning of a lacustrine record (Rennes Basin, France)
}

Slah Boulila et al.

Correspondence to: Slah Boulila (slah.boulila@sorbonne-universite.fr)

The copyright of individual parts of the supplement might differ from the article licence. 


\section{S1. Biostratigraphic framework}

\begin{tabular}{|c|c|c|c|c|c|}
\hline Lithostratigraphic unit & Samples & Micropaleontology & Palynology & Malacology & Total \\
\hline Azoic Sands Fm & - & - & - & - & - \\
\hline Faluns and Lithothamniids Fm & 5 & 5 & - & - & 5 \\
\hline Upper Sapropels Fm & 3 & 3 & 3 & - & 6 \\
\hline Archiacina Limestones Fm & 5 & 5 & 1 & - & 6 \\
\hline Natica Marls Fm & 6 & 4 & 3 & 1 & 8 \\
\hline Lower Sapropels Fm & 52 & 6 & 49 & - & 55 \\
\hline Chartres-de-Bretagne Fm & 24 & 6 & 22 & - & 28 \\
\hline TOTAL & 95 & 29 & 78 & 1 & 108 \\
\hline
\end{tabular}

Table S1. Sample distribution and biostratigraphical analyses with regard to lithostratigraphic units. Palynology is the main analysis conducted, for the numerous organic-rich clay deposits occurrences. 


\begin{tabular}{|c|c|c|c|c|c|c|c|}
\hline \multicolumn{2}{|c|}{ Depth (m) } & \multirow{2}{*}{\multicolumn{2}{|c|}{$\begin{array}{c}\text { Index fossils } \\
\text { (foraminifers, pollen grains, } \\
\text { dinocysts) } \\
\end{array}$}} & \multirow{2}{*}{$\begin{array}{l}\text { Biozone or } \\
\text { stratigraphic horizon }\end{array}$} & \multirow{2}{*}{$\begin{array}{c}\text { Age / Stage } \\
\text { Informal age / stage }\end{array}$} & \multirow{2}{*}{$\begin{array}{l}\text { Num. } \\
\text { age (Ma) }\end{array}$} & \multirow{2}{*}{ References } \\
\hline Min. & Max. & & & & & & \\
\hline 0.00 & 4.00 & \multicolumn{2}{|l|}{-} & - & \multirow{2}{*}{ Langhian to Serravallian } & & $\begin{array}{l}\text { Van Vliet-Lanoë et al } \\
1998\end{array}$ \\
\hline 4.00 & 25.50 & \multicolumn{2}{|c|}{$\begin{array}{l}\text { Elphidium spp. \& P. serrata } \\
\text { assemblage }\end{array}$} & - & & & $\begin{array}{l}\text { Margerel \& Bréhéret, } \\
1984 \text {; Margerel, } 2009\end{array}$ \\
\hline 30.00 & 33.00 & \multicolumn{2}{|c|}{$\begin{array}{l}\text { LO of } P \text {. armorica, N. viennoti, } \\
V . \text { kasselensis, B. beyrichi }\end{array}$} & $\begin{array}{l}\text { Top of SBZ21 = top of } \\
\text { P19 biozone }\end{array}$ & \multirow{3}{*}{ Rupelian } & 30.3 & $\begin{array}{l}\text { Cahuzac and Poignant } \\
\text { (1997); Vandenberghe } \\
\text { et al. (2012) }\end{array}$ \\
\hline 33.00 & 66.65 & LO & \multirow{2}{*}{$\begin{array}{l}\text { C. giuseppei, } \\
\text { I. multispinosum, } \\
\text { V. ceraichia }\end{array}$} & Top of D14na & & 30.6 & \multirow{2}{*}{$\begin{array}{l}\text { Köthe }(2003,2012) \\
\text { Köthe and Piesker, } \\
2007 .\end{array}$} \\
\hline 83.20 & 133.66 & FO & & Base of D14na & & 32.3 & \\
\hline 133.66 & 195.12 & \multicolumn{2}{|c|}{$\begin{array}{l}\text { LO of } A \text {. cyclops } \\
\text { FO of SI. hippophaeoides \& } \\
\text { C. simplex }\end{array}$} & $\begin{array}{l}\text { 'La Rivardière / Matival' } \\
\text { pollen assemblage }\end{array}$ & $\begin{array}{l}\text { Early Rupelian } \\
\text { (Sannoisian of the Paris } \\
\text { Basin) }\end{array}$ & $\begin{array}{l}32.3 \text { to } \\
\text { ca } 33\end{array}$ & $\begin{array}{l}\text { Châteauneuf (1980) } \\
\text { Ollivier-Pierre (1980) }\end{array}$ \\
\hline 195.12 & 196.29 & \multicolumn{2}{|c|}{$\begin{array}{l}\text { FO of B. hohli, M. vanwijkei, } \\
\text { Chloranthaceae: Chloranthus \& } \\
\text { Sarcandia sp. }\end{array}$} & $\begin{array}{l}\text { Western European } \\
\text { biomarkers }\end{array}$ & Earliest Rupelian & $\begin{array}{l}\text { ca } 33 \text { to } \\
33.9\end{array}$ & $\begin{array}{l}\text { Sittler et al. (1975); } \\
\text { Châteauneuf (1980) }\end{array}$ \\
\hline 205.97 & 265.87 & \multicolumn{2}{|c|}{$\begin{array}{l}\text { LO of } T \text {. cognitus \& } P \text {. crassus } \\
\text { FO of } T \text {. raguhnensis, } T \text {. } \\
\text { densus \& } T \text {. rhombus }\end{array}$} & $\begin{array}{l}\text { Classic assemblage } \\
\text { from the Paris Basin }\end{array}$ & Late Priabonian & $\begin{array}{l}33.9 \text { to ca } \\
35\end{array}$ & Châteauneuf (1980) \\
\hline 277,99 & 374.97 & \multicolumn{2}{|c|}{$\begin{array}{l}\text { Bloom of Hamamelidaceae and } \\
\text { A. cyclops } \\
\text { FO of P. calauensis } \\
\text { LO of Diporites, R. loburgensis }\end{array}$} & Regional markers & Lower Priabonian & $\begin{array}{l}\text { ca } 35 \text { to } \\
37.8 \pm \\
0.5\end{array}$ & $\begin{array}{l}\text { Châteauneuf (1980) } \\
\text { Ollivier-Pierre (1980) }\end{array}$ \\
\hline 379.10 & 391.53 & \multicolumn{2}{|c|}{$\begin{array}{l}\text { LO of } P \text {. subhercynicus, } \\
\text { FO of } T \text {. clavatus \& } T \text {. sauerae }\end{array}$} & Regional markers & Late Bartonian & $\begin{array}{l}37.8 \pm \\
0.5 \text { to } \\
38.33\end{array}$ & $\begin{array}{l}\text { Châteauneuf (1980) } \\
\text { Ollivier-Pierre (1980) } \\
\text { Schuler (1988) }\end{array}$ \\
\hline 392.32 & 399.88 & \multicolumn{2}{|c|}{$\begin{array}{l}\text { LO of C. parisiensis, C. } \\
\text { columnatortilis, A. kerfornei, V. } \\
\text { globularis, Normapolles group, } \\
\text { Bombacacidites Spp., Nypa } \\
\text { FO of R. loburgensis }\end{array}$} & $\begin{array}{l}\text { Top of SBZ17 = base of } \\
\text { C17n3n }\end{array}$ & $\begin{array}{l}\text { Top of Biarritzian (middle } \\
\text { /late Bartonian boundary) }\end{array}$ & 38.33 & $\begin{array}{l}\text { Châteauneuf (1980) } \\
\text { Ollivier-Pierre (1980) } \\
\text { Serra-Kiel et al. (1998); } \\
\text { Vandenberghe et al. } \\
(2012)\end{array}$ \\
\hline 399.88 & $\mathrm{mel}_{\text {Below }}^{401.70}$ & \multicolumn{2}{|c|}{$\begin{array}{l}\text { FO of C. parisiensis, C. } \\
\text { columnatortilis, A. kerfornei, V. } \\
\text { globularis }\end{array}$} & SBZ17 & $\begin{array}{l}\text { Biarritzian (early - middle } \\
\text { Bartonian) }\end{array}$ & $\begin{array}{l}38.33 \text { to } \\
41.2 \pm \\
0.5\end{array}$ & $\begin{array}{l}\text { Serra-Kiel et al. (1998); } \\
\text { Vandenberghe et al. }\end{array}$ \\
\hline
\end{tabular}

Table S2. Depth intervals of relevant biostratigraphic limits, and corresponding numerical ages according to the GTS2012 (Vandenberghe et al., 2012). SBZ refer to Shallow Benthic Zone; D14na refer to Dinocysts biozonation from Köthe (2003); FO for First Occurrence, LO for Last Occurrence. See Bauer et al. (2016) for reference taxa. Numerical ages are either calibrated (bold) or estimated (italic). The "Biarritzian" regional stage was defined by Hottinger and Schaub (1960), the equivalence with benthic foraminifera was given by Cavelier et Le Calvez (1965). Subsequently Serra-Kiel et al. (1998) gave precisions on its stratigraphic position according to international standard (equivalent to SBZ17). In the GTS2012 (Vandenberghe et al., 2012), the top SBZ17 is coeval with the base of C17n3n. The Bartonian/Priabonian boundary is better constrained in the Borehole CDB1 than it is in the Paris Basin to which it is compared.. The Eocene-Oligocene boundary is well constrained in the Borehole CDB1, in between the LO of exclusively Priabonian assemblages and the FO of Boehlensipollis hohli (Sittler et al., 1975; Sittler and Schuler, 1976; Schuler and Sittler, 1976; Châteauneuf, 1980; Ionescu and Alexandrescu, 1995; King, 2016), covering a $<10$ m-thick interval. The D14na dinocysts subzone was defined by Köthe (2003; Köthe and Piesker, 2007), then correlated with nannofossil biozones (Köthe, 2012). The choice of this dinocyst biozonation is motivated because it is built upon recent (2000's) German data, and from a closer location to our place, together with a very good correlation between dinocysts and nannofossils. However, to ensure a consistent dataset, ages from Köthe (2012) were updated according to ages from the GTS2012. The SBZ21 was defined by Cahuzac and Poignant (1997); its top limit was correlated with top of P19 biozone from Berggren et al. (1995). 


\section{S2. Rock magnetism analyses and magnetostratigraphy}
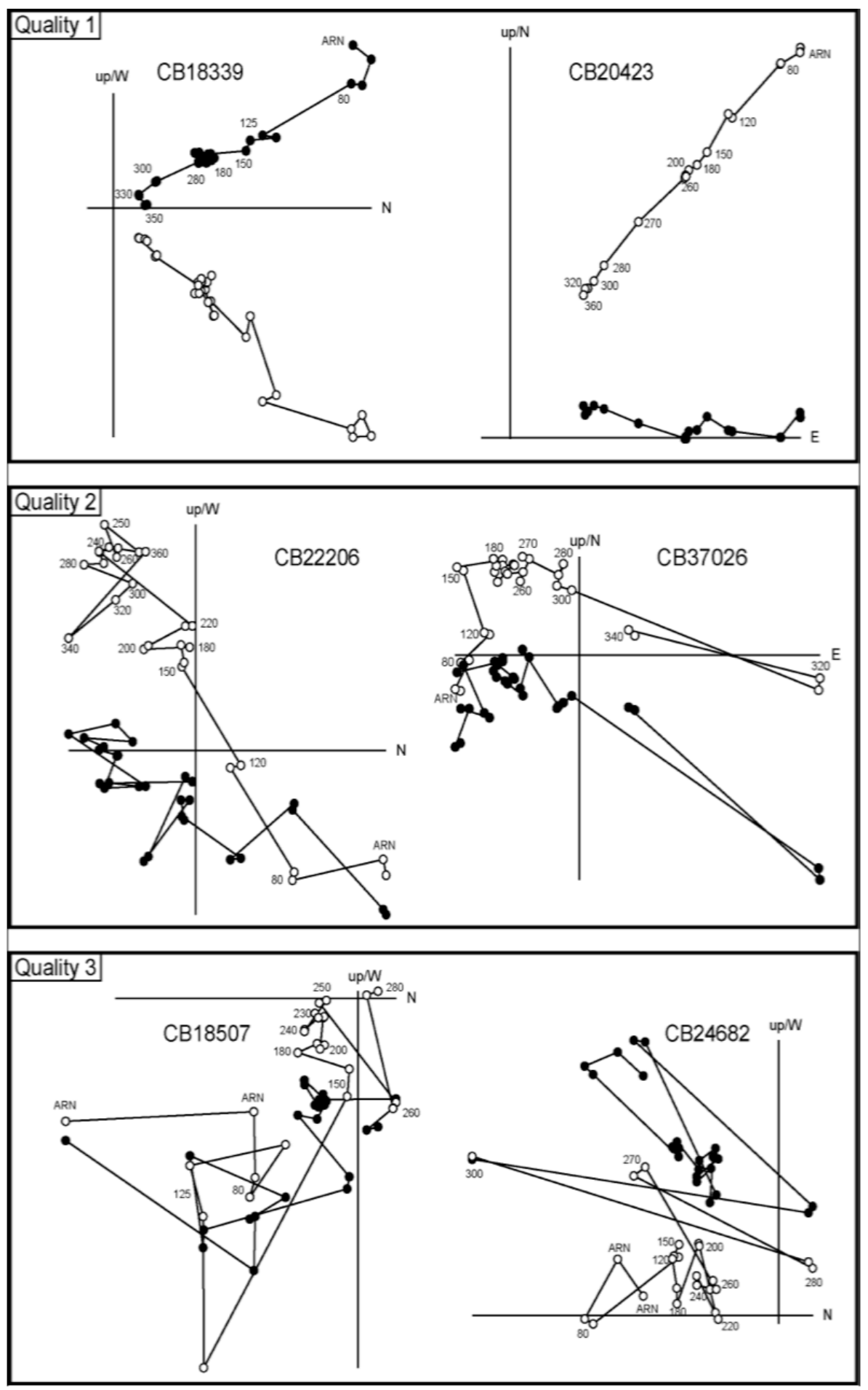

Figure S1. Charateristic thermal demagnetization diagrams. Open (full) symbols are projections in the vertical (horizontal) plane. Quality 1 (Q1) are ChRM directions of normal or reversed polarity from which a well-defined direction was determined from stable and linear demagnetization paths, yielding MAD typically below $15^{\circ}$. Quality 2 (Q2) directions have clearly defined normal or reversed polarities but the directions are less reliable because of paths not-fully demagnetized to the origin, directional scatter and/or overlapping secondary overprint. Quality 3 (Q3) yielded demagnetizations from which neither directions nor polarity could be interpreted and were rejected from further analyses. 


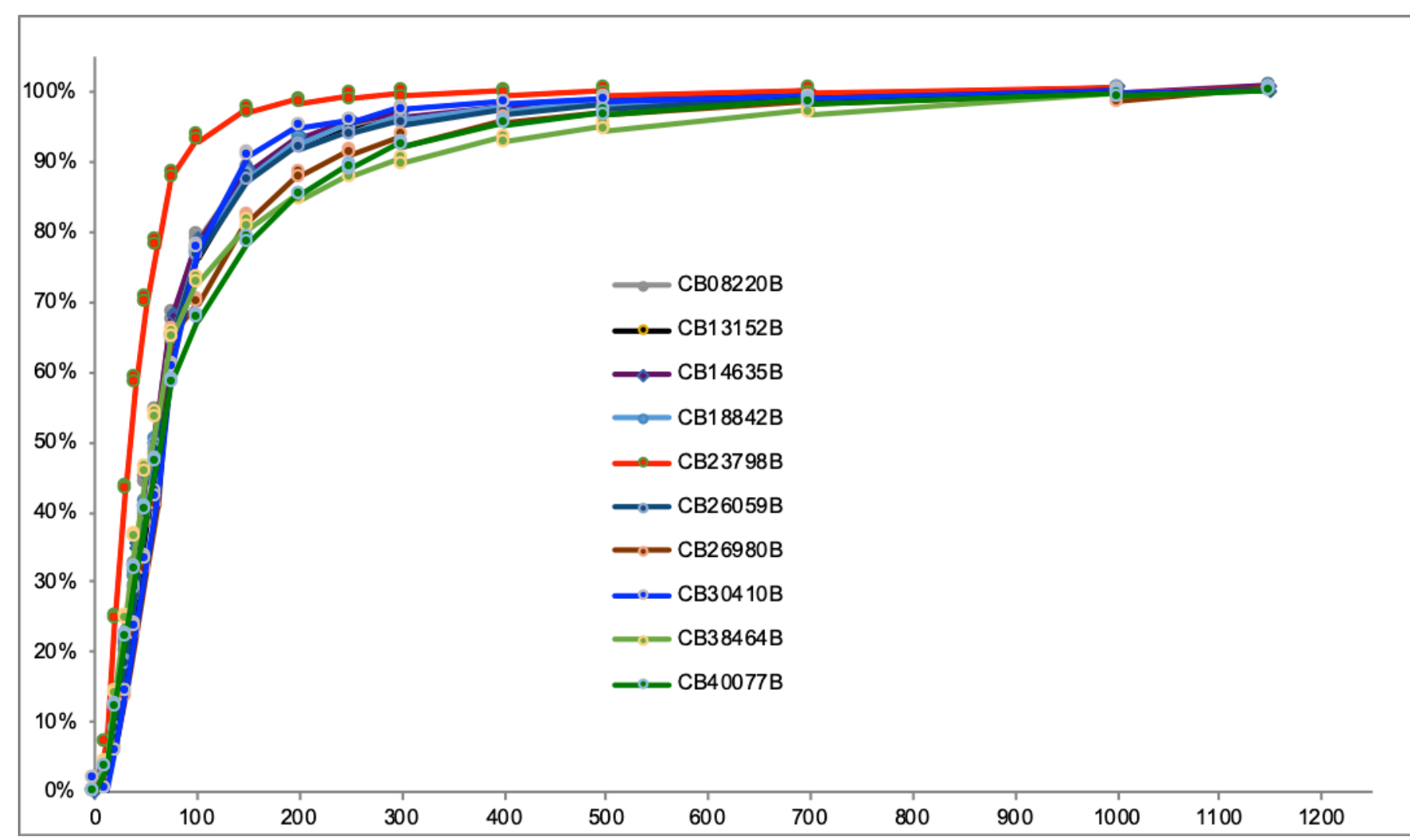

Figure S2a. Rock magnetic behaviours of 10 representative samples throughout the sampled interval. Isothermal Remanent Magnetization (IRM) acquisition at increasing fields in $50 \mathrm{mT}$ steps up to $1200 \mathrm{mT}$.

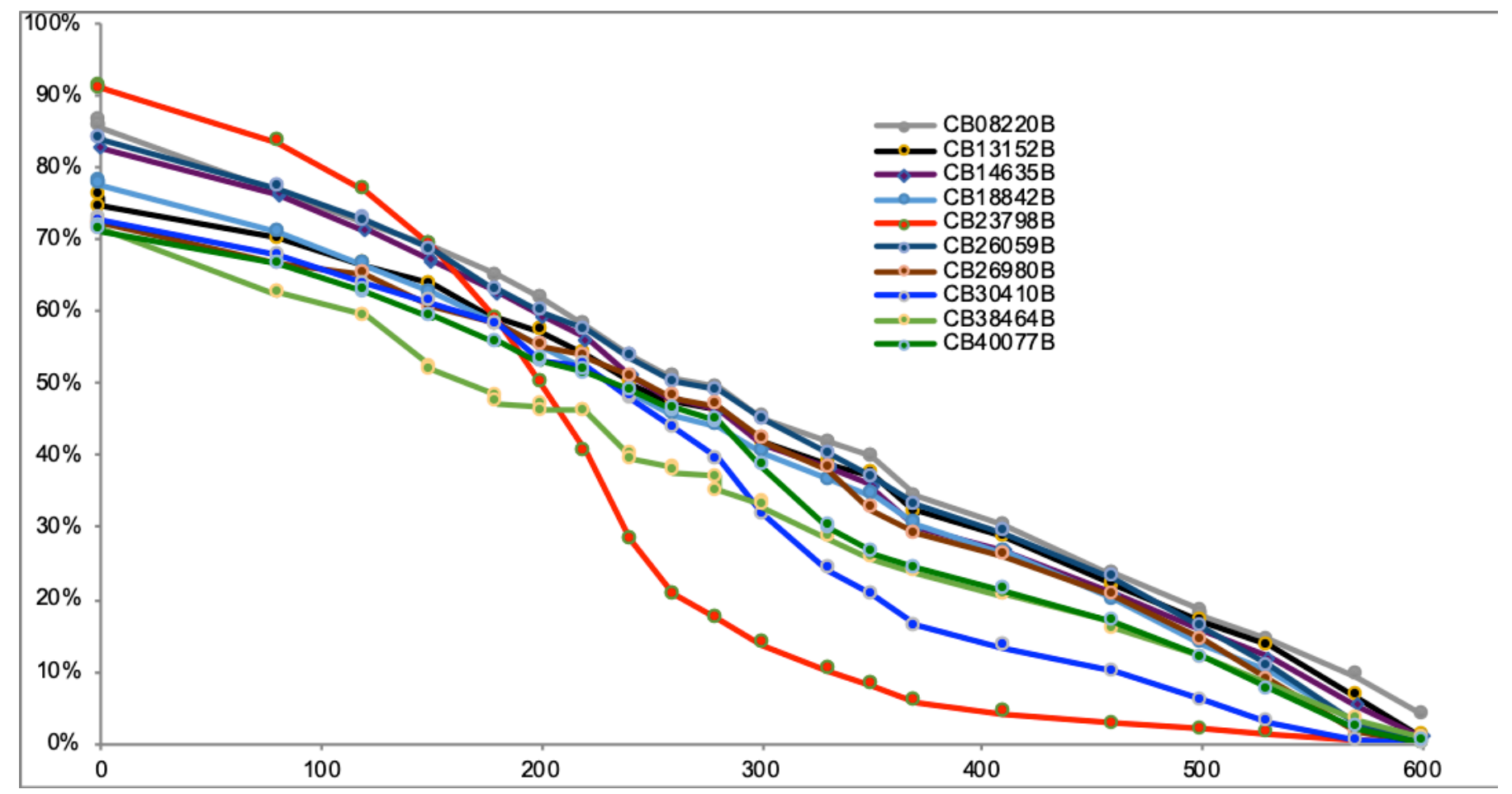

Figure S2b. Rock magnetic behaviours of 10 representative samples throughout the sampled interval. Thermal demagnetization at increasing temperatures up to $600^{\circ} \mathrm{C}$ of the soft coercivity component $(<125 \mathrm{mT})$ expressed as it percentage of the total IRM. 


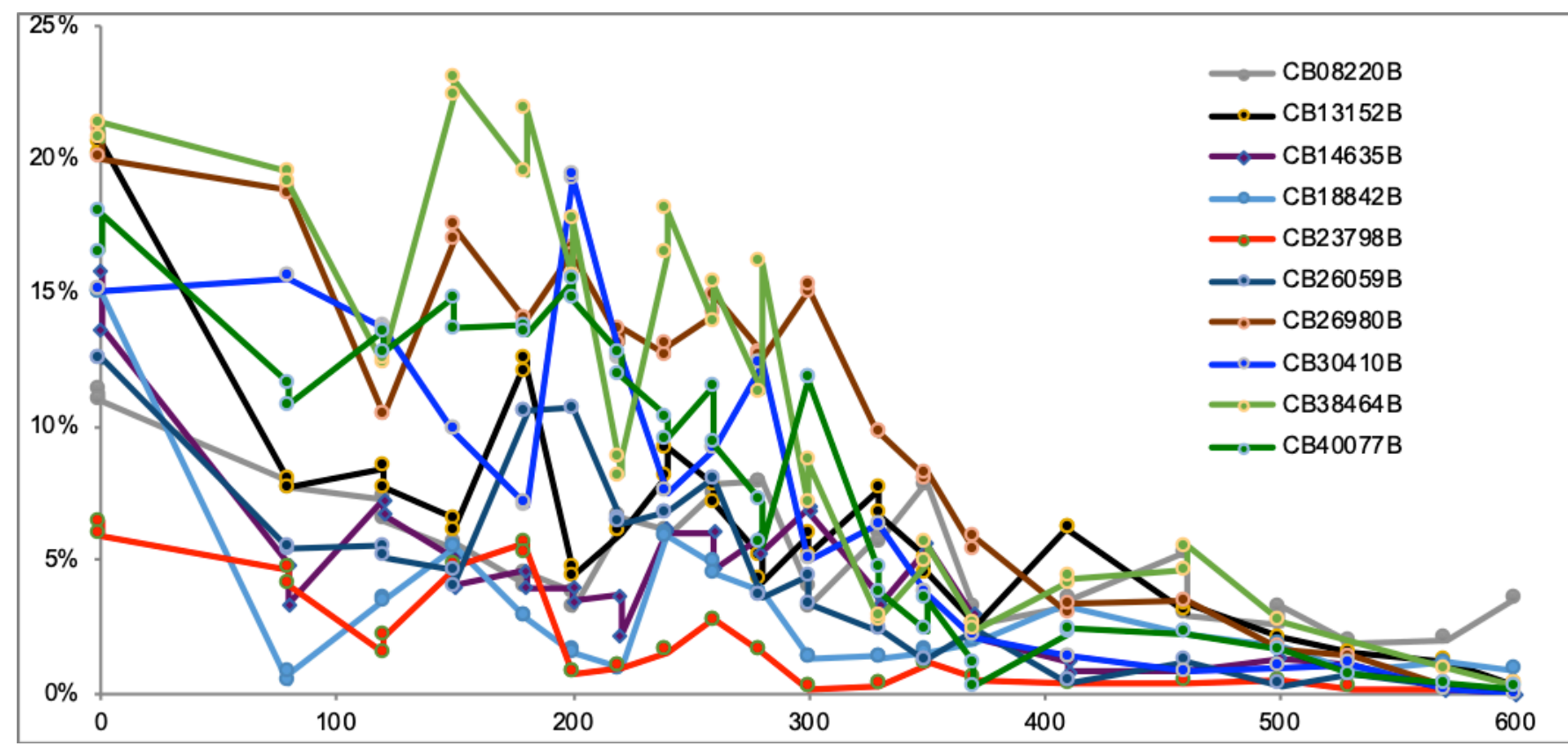

Figure S2c. Rock magnetic behaviours of 10 representative samples throughout the sampled interval. Thermal demagnetization at increasing temperatures up to $600^{\circ} \mathrm{C}$ of the intermediate coercivity component $(125-400 \mathrm{mT})$ expressed as it percentage of the total IRM.

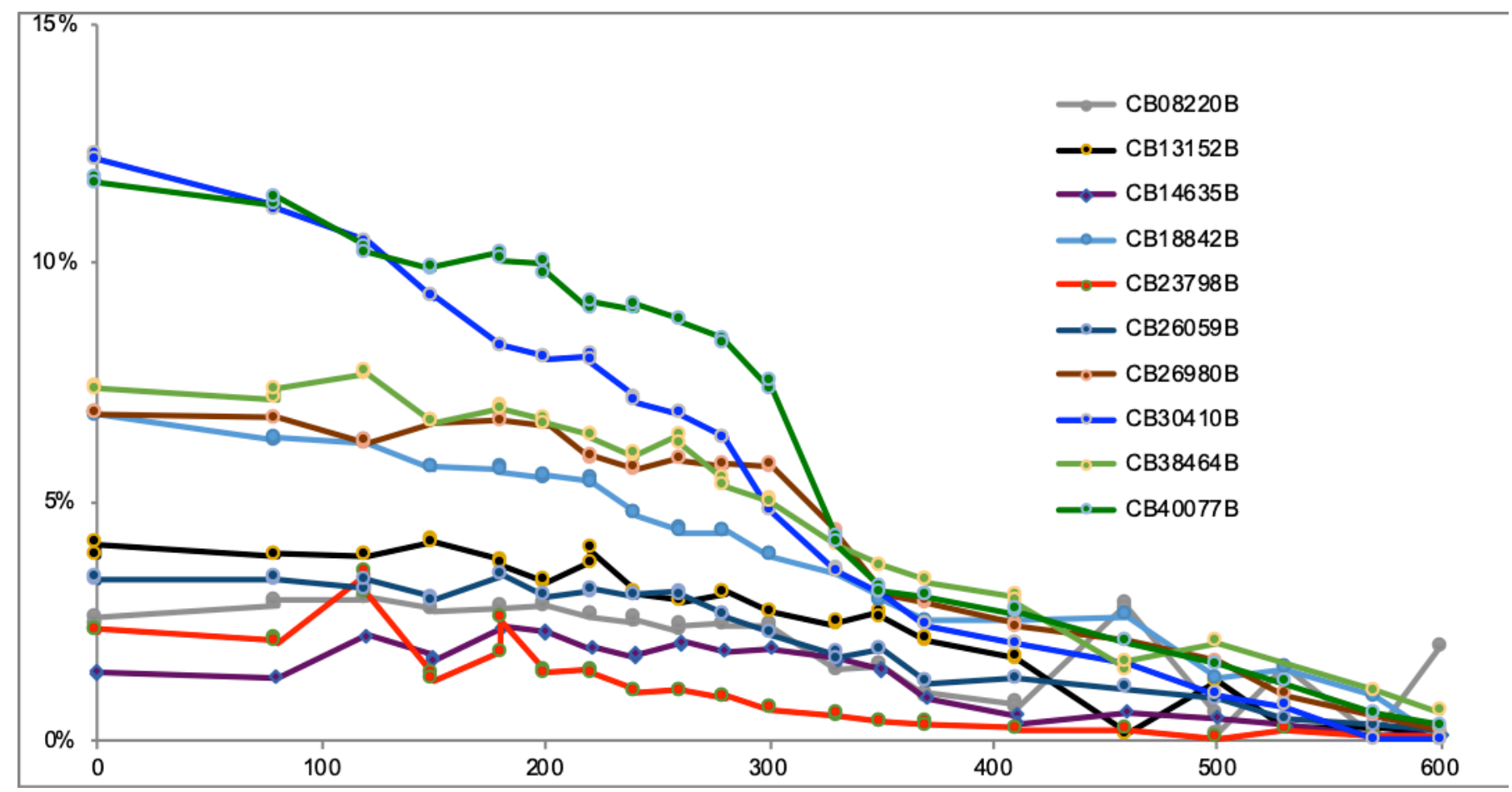

Figure S2d. Rock magnetic behaviours of 10 representative samples throughout the sampled interval. Thermal demagnetization at increasing temperatures up to $600^{\circ} \mathrm{C}$ of the strong coercivity component $(400-1200 \mathrm{mT})$ expressed as it percentage of the total IRM. 


\section{Inclination Corr. A GPTS Corr. B \\ 2012}

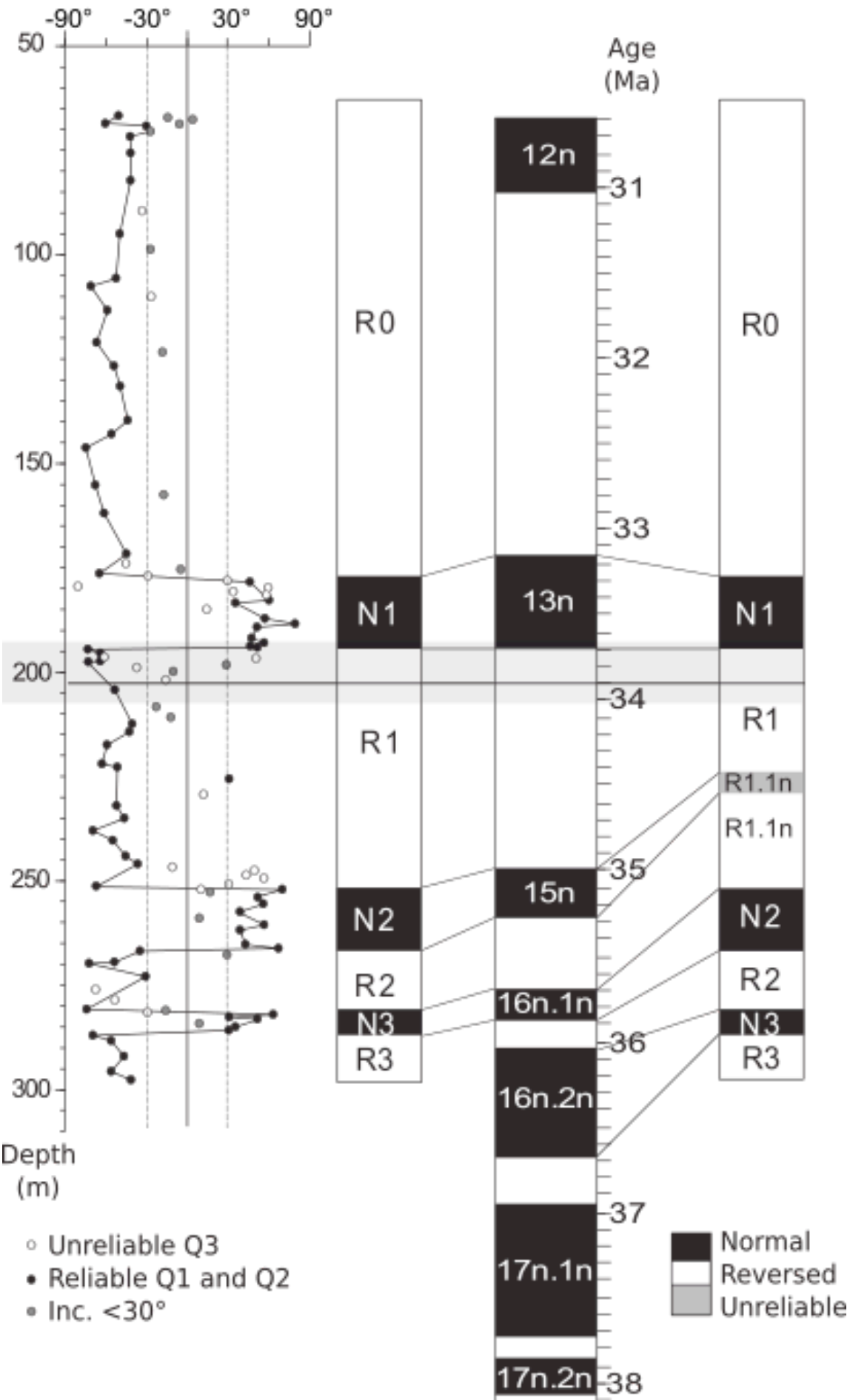

Figure S3. Magnetostratigraphic results and correlation to the Geomagnetic Polarity Time Scale (GPTS; Vandenberghe, 2012). Inclination - Inclinations of Characteristic Remanent Magnetizations from samples obtained though the stratigraphic depth. Positive (negative) inclinations indicate normal (reversed) polarities. Black symbols indicate reliable polarities (Qualities 1 and 2, see Fig. SI-1) and unreliable polarities are indicated in white (Quality 3, see Fig. SI-1) and grey for inclinations within $\pm 30^{\circ}$ that were systematically rejected. Polarity zones R0 to R3 and N1 to N3 are based on several consecutive reliable inclinations, R1.1n based on only one inclination is unreliable. EOB - Eocene-Oligocene Boundary indicated by grey area is defined by the 
pollen transition in the stratigraphic log between 195.08 and $205.99 \mathrm{~m}$ depth. Corr. A and Corr. B show proposed correlations to the GPTS. Correlation B including R1.1n is found unlikely. This polarity zone is defined by only 1 normal direction ca. $230 \mathrm{~m}$ depth. Correlating R1.1n with $\mathrm{C} 15 \mathrm{n}$ would imply the above polarity zones N1 and $\mathrm{R} 0$ to correlate to $\mathrm{C} 13 \mathrm{n}$ and $\mathrm{C} 12 \mathrm{r}$ respectively, similar to correlation B. However, N2 and N3 below would have to correlate to $\mathrm{C} 16 \mathrm{n} .1 \mathrm{n}$ and $\mathrm{C} 16 \mathrm{n} .2 \mathrm{n}$ respectively although $\mathrm{N} 2$ is larger than N3 while $\mathrm{C} 16 \mathrm{n}$. $1 \mathrm{n}$ is much shorter than C16n.2n. Also, R3 in between is much too large to account for the the short C16n.1r. Correlation B would imply unrealistic accumulation rate variations through the section such that it is clearly disfavored compared to the excellent fit provided by correlation A which is used for further analyses.

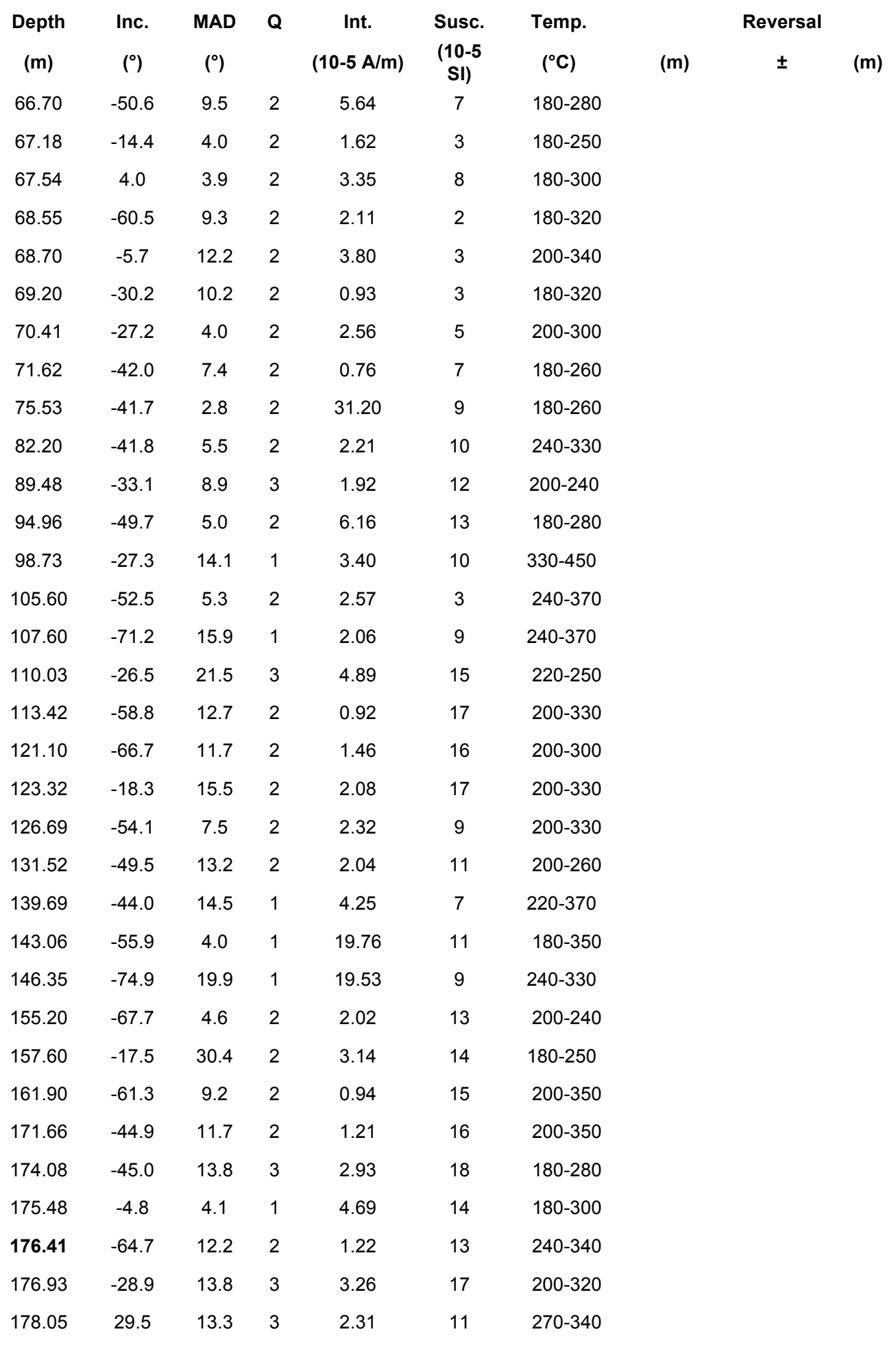




\begin{tabular}{|c|c|c|c|c|c|c|c|c|c|}
\hline 178.46 & 46.1 & 8.8 & 2 & 4.43 & 12 & $180-300$ & 177.44 & \pm & 1.03 \\
\hline 179.48 & -80.6 & 8.7 & 3 & 3.02 & 10 & $230-250$ & & & \\
\hline 179.82 & 59.5 & 14.6 & 3 & 3.89 & 13 & $0-200$ & & & \\
\hline 180.82 & 33.7 & 8.0 & 3 & 5.47 & 9 & $250-280$ & & & \\
\hline 181.49 & 58.4 & 4.5 & 3 & 5.03 & 7 & $230-250$ & & & \\
\hline 182.80 & 60.2 & 15.0 & 1 & 9.79 & 6 & $180-360$ & & & \\
\hline 183.39 & 35.4 & 3.5 & 1 & 20.06 & 6 & $180-330$ & & & \\
\hline 185.07 & 14.5 & 7.0 & 3 & 4.43 & 13 & $200-230$ & & & \\
\hline 187.20 & 57.0 & 4.1 & 2 & 4.53 & 7 & $180-250$ & & & \\
\hline 188.42 & 79.3 & 25.1 & 1 & 4.83 & 5 & $80-300$ & & & \\
\hline 189.22 & 51.4 & 3.8 & 1 & 19.62 & 9 & $180-350$ & & & \\
\hline 191.88 & 47.3 & 22.1 & 1 & 12.26 & 8 & $200-370$ & & & \\
\hline 192.94 & 56.3 & 5.2 & 1 & 10.70 & 9 & $180-350$ & & & \\
\hline 193.79 & 46.4 & 2.6 & 1 & 47.41 & 11 & $180-350$ & & & \\
\hline 194.15 & 51.6 & 3.9 & 1 & 10.75 & 12 & $180-360$ & & & \\
\hline 194.62 & -73.2 & 4.0 & 1 & 98.09 & 11 & $180-350$ & 194.39 & \pm & 0.23 \\
\hline 195.58 & -64.2 & 4.5 & 1 & 175.04 & 15 & $180-350$ & & & \\
\hline 196.51 & -61.1 & 17.7 & 3 & 3.31 & 14 & $180-230$ & & & \\
\hline 196.80 & 50.6 & 22.2 & 3 & 1.93 & 13 & $250-340$ & & & \\
\hline 197.33 & -64.0 & 2.0 & 1 & 204.79 & 13 & $180-350$ & & & \\
\hline 197.59 & -72.8 & 11.6 & 2 & 1.33 & 12 & $240-350$ & & & \\
\hline 198.33 & 28.7 & 19.1 & 2 & 1.27 & 13 & $220-300$ & & & \\
\hline 198.95 & -37.4 & 30.5 & 3 & 2.30 & 13 & $180-280$ & & & \\
\hline 199.88 & -10.4 & 3.8 & 2 & 1.71 & 12 & $200-300$ & & & \\
\hline 202.01 & -15.9 & 14.1 & 3 & 5.39 & 10 & $180-230$ & & & \\
\hline 204.23 & -53.3 & 3.9 & 1 & 63.79 & 7 & $150-360$ & & & \\
\hline 208.30 & -22.8 & 16.5 & 2 & 1.48 & 5 & $200-280$ & & & \\
\hline 210.85 & -12.2 & 1.0 & 1 & 101.21 & 6 & $180-360$ & & & \\
\hline 212.44 & -40.7 & 9.9 & 2 & 3.35 & 2 & $180-250$ & & & \\
\hline 214.35 & -42.6 & 26.3 & 1 & 2.74 & 7 & $200-330$ & & & \\
\hline 217.39 & -59.2 & 6.9 & 1 & 9.08 & 7 & $180-340$ & & & \\
\hline 222.06 & -62.9 & 10.7 & 2 & 1.98 & 6 & $220-340$ & & & \\
\hline 222.73 & -51.6 & 4.5 & 2 & 19.89 & 7 & $180-320$ & & & \\
\hline 225.55 & 30.8 & 6.1 & 1 & 3.57 & 1 & $180-360$ & & & \\
\hline 229.35 & 11.9 & 21.6 & 3 & 0.65 & 14 & $180-270$ & & & \\
\hline 231.98 & -52.2 & 3.0 & 2 & 7.59 & 10 & $150-280$ & & & \\
\hline 235.03 & -46.4 & 7.1 & 1 & 125.53 & 8 & $180-350$ & & & \\
\hline 237.98 & -69.5 & 8.4 & 1 & 248.04 & 14 & $220-370$ & & & \\
\hline 240.33 & -54.9 & 12.3 & 2 & 74.69 & 8 & $220-340$ & & & \\
\hline 244.08 & -45.5 & 5.3 & 2 & 7.50 & 6 & $180-350$ & & & \\
\hline 245.99 & -36.7 & 28.3 & 2 & 0.92 & 4 & $150-330$ & & & \\
\hline 246.82 & -11.1 & 3.9 & 3 & 1.98 & 5 & $240-260$ & & & \\
\hline 247.61 & 49.3 & 6.2 & 3 & 11.47 & 2 & $180-280$ & & & \\
\hline
\end{tabular}




\begin{tabular}{|c|c|c|c|c|c|c|c|c|c|}
\hline 248.71 & 43.4 & 9.1 & 3 & 4.83 & 4 & $200-240$ & & & \\
\hline 249.48 & 56.3 & 12.9 & 3 & 8.67 & 8 & $180-280$ & & & \\
\hline 250.80 & 30.5 & 9.2 & 3 & 6.90 & 10 & $200-280$ & & & \\
\hline 251.34 & -67.0 & 4.4 & 1 & 49.57 & 8 & $180-350$ & & & \\
\hline 252.04 & 69.7 & 1.4 & 1 & 156.05 & 7 & $180-360$ & 251.69 & \pm & 0.35 \\
\hline 252.16 & 10.1 & 5.1 & 3 & 8.91 & 6 & $250-350$ & & & \\
\hline 252.72 & 16.9 & 16.7 & 1 & 9.52 & 6 & $260-330$ & & & \\
\hline 254.05 & 51.9 & 8.8 & 1 & 12.87 & 6 & $180-330$ & & & \\
\hline 255.49 & 55.8 & 5.3 & 1 & 11.62 & 7 & $180-350$ & & & \\
\hline 257.37 & 38.6 & 4.0 & 1 & 8.88 & 9 & $180-350$ & & & \\
\hline 259.07 & 8.9 & 5.0 & 2 & 24.77 & 8 & $180-260$ & & & \\
\hline 260.59 & 56.4 & 14.2 & 1 & 15.84 & 5 & $150-370$ & & & \\
\hline 261.90 & 38.7 & 4.7 & 1 & 23.13 & 5 & $180-330$ & & & \\
\hline 265.29 & 42.6 & 4.5 & 1 & 13.84 & 7 & $180-350$ & & & \\
\hline 266.17 & 67.0 & 9.0 & 1 & 1.96 & 8 & $180-340$ & & & \\
\hline 266.91 & -33.7 & 5.3 & 2 & 11.45 & 8 & $200-350$ & 266.54 & \pm & 0.37 \\
\hline 267.72 & 29.3 & 13.1 & 2 & 1.44 & 8 & $180-300$ & & & \\
\hline 269.58 & -53.5 & 3.1 & 1 & 15.93 & 2 & $180-360$ & & & \\
\hline 269.80 & -72.4 & 9.6 & 1 & 3.24 & 1 & $260-450$ & & & \\
\hline 273.02 & -30.9 & 13.6 & 2 & 3.94 & 4 & $180-280$ & & & \\
\hline 276.02 & -67.4 & 7.7 & 3 & 2.49 & 20 & $180-230$ & & & \\
\hline 278.59 & -53.4 & 7.3 & 3 & 2.64 & 14 & $280-350$ & & & \\
\hline 280.79 & -74.2 & 7.1 & 2 & 5.01 & 13 & $180-250$ & & & \\
\hline 281.14 & -15.9 & 19.4 & 2 & 4.73 & 8 & $180-320$ & & & \\
\hline 281.59 & -29.4 & 12.8 & 3 & 3.05 & 10 & $200-300$ & & & \\
\hline 282.10 & 63.1 & 8.3 & 1 & 6.52 & 10 & $220-320$ & 281.45 & \pm & 0.66 \\
\hline 282.66 & 31.0 & 7.0 & 2 & 8.44 & 10 & $180-250$ & & & \\
\hline 283.15 & 51.7 & 2.9 & 1 & 11.56 & 11 & $200-360$ & & & \\
\hline 284.17 & 9.0 & 6.6 & 2 & 27.30 & 15 & $220-340$ & & & \\
\hline 285.10 & 35.4 & 20.6 & 2 & 1.76 & 5 & $200-280$ & & & \\
\hline 285.85 & 30.5 & 6.5 & 2 & 3.27 & 3 & $220-280$ & & & \\
\hline 287.08 & -69.4 & 3.1 & 1 & 1.70 & 21 & $180-350$ & 286.47 & \pm & 0.61 \\
\hline 288.36 & -56.2 & 9.5 & 2 & 11.30 & 10 & $180-250$ & & & \\
\hline 292.12 & -46.7 & 12.2 & 2 & 5.16 & 6 & $180-280$ & & & \\
\hline 295.63 & -56.3 & 4.4 & 1 & 4.27 & 4 & $180-350$ & & & \\
\hline 297.76 & -41.5 & 6.7 & 2 & 7.14 & 5 & $180-330$ & & & \\
\hline
\end{tabular}

Table S3. Depth - Stratigraphic depth below surface in meters; Inc. - Inclination of Characteristic Remanent direction determined from demagnetization path (ChRM); MAD - Maximum Angular Deviation from line fit of demagnetization path to determine ChRM direction; $\mathbf{Q}$ - Quality of ChRM inclination, 1 for Quality 1 with reliable direction and polarity, 2 for Quality 2 with reliable polarity but unreliable direction, 3 for Quality 3 with unreliable direction and polarity; Int. - Magnetic intensity of determined ChRM direction; Susc. - Magnetic Susceptibility of Natural Remanent Magnetization (NRM); Temp. -Temperature range used to determine ChRM direction; Reversal - Stratigraphic position of identified reversals positioned between 2 successive reliable directions of opposite polarities. 


\section{S3. Cyclostratigraphy}

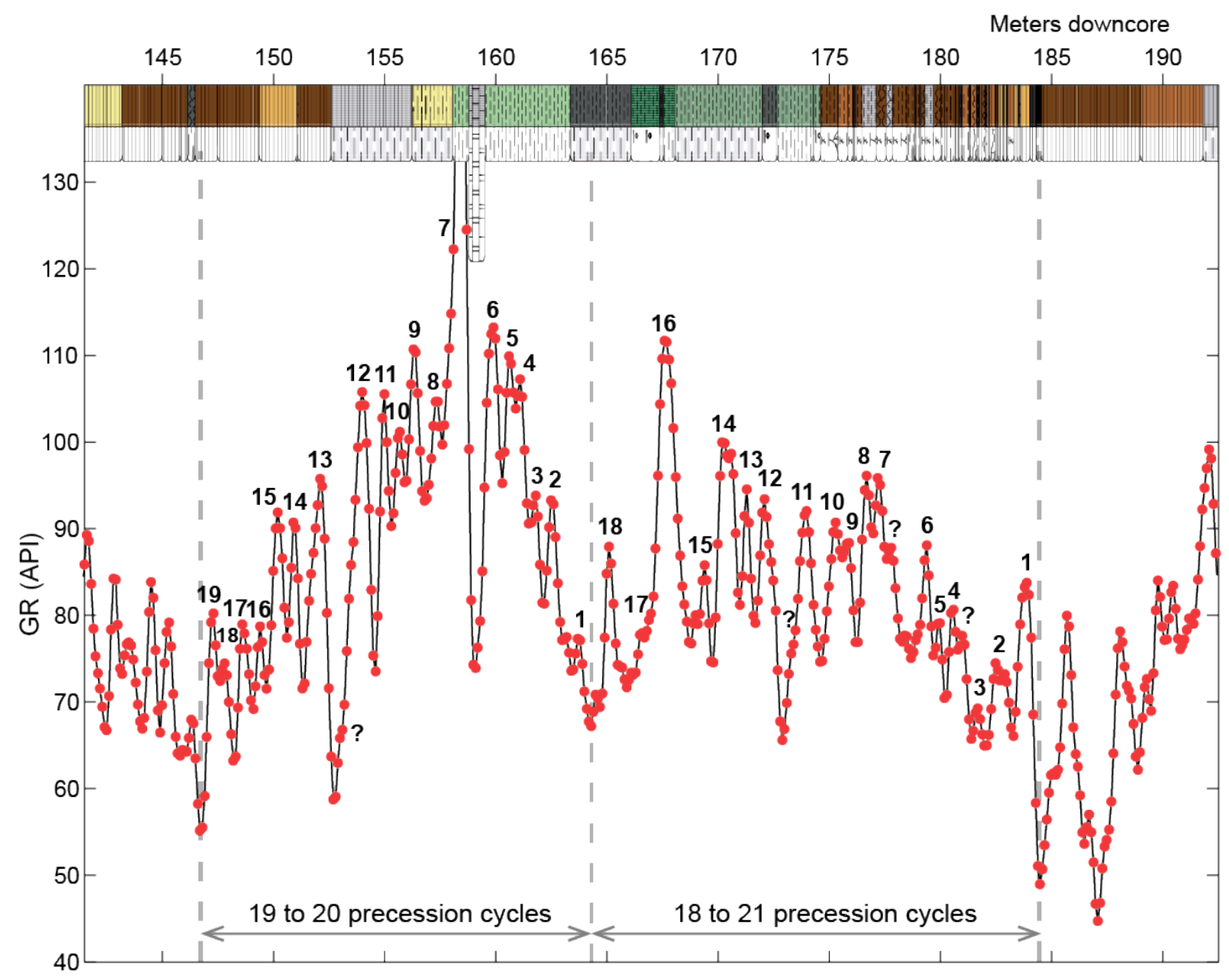

Figure S4. Illustration of counting of meter-scale cycles (precession) within the $\sim 20 \mathrm{~m}$ cycles (405 kyr eccentricity) in interval I1. The vertical dashed lines delimit the $\sim 20 \mathrm{~m}$ cycles. 


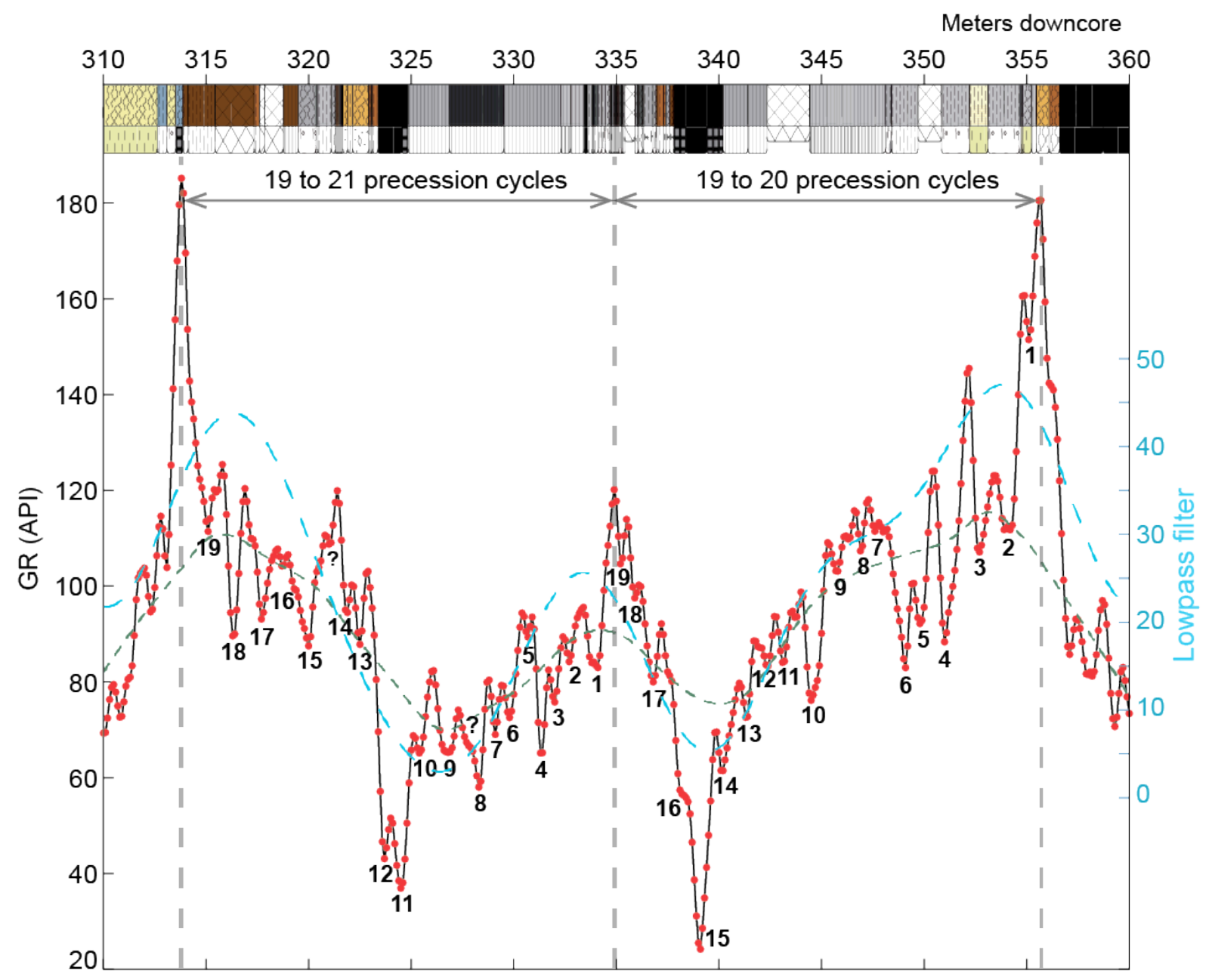

Figure S5. Illustration of counting of meter-scale cycles (precession) within the $\sim 20 \mathrm{~m}$ cycles (405 kyr eccentricity) in interval I2. The vertical dashed lines delimit the $\sim 20 \mathrm{~m}$ cycles. A low-pass filtering and a smoothing are applied to highlight the $\sim 20$ m cycles. 

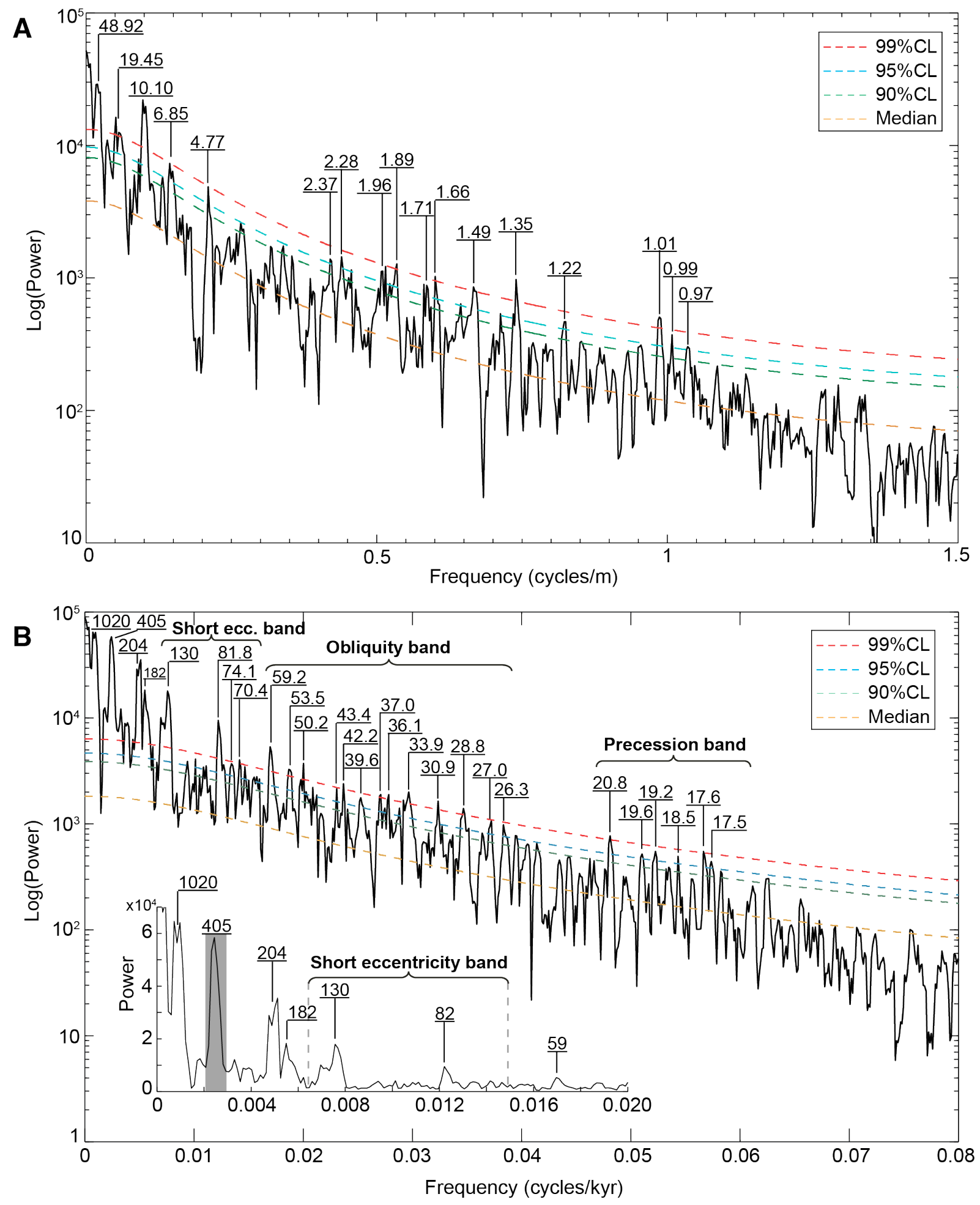

Figure S6. Time-series analysis of the untuned and tuned gamma-ray variations for the interval from 65.5 to 406 m. (A) $2 \pi$-MTM power spectrum of the untuned raw GR. Spectral periods are expressed in meters. (B) $2 \pi-M T M$ power spectrum of the $405 \mathrm{kyr}$ tuned GR. Spectral periods are expressed in kiloyears. Inset: spectrum over [0, $0.02 \mathrm{cycles} / \mathrm{kyr}]$ to show the low-frequency portion of the spectrum, with the grey-shaded peak corresponds to the target period for tuning. 

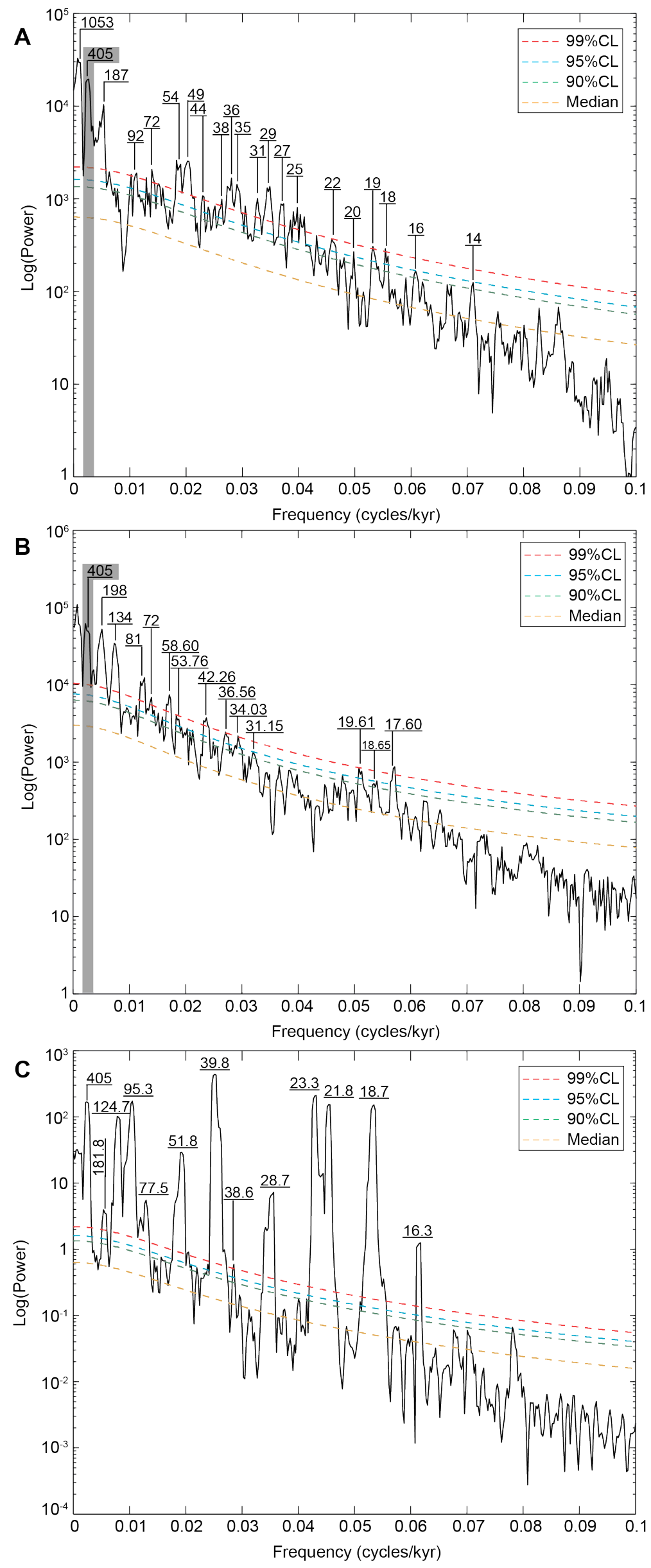
Figure S7. Time-series analysis of the tuned gamma-ray (GR) variations per intervals I1 and I2 (as in Fig. 2 but in time domain) and comparison with astronomical frequencies. (A) $2 \pi$-MTM power spectrum of interval I1. (B) $2 \pi$-MTM power spectrum of interval I2. Grey-shaded vertical bars in 'A' and 'B' indicate the target $405 \mathrm{kyr}$ periodicity used to time-calibrate the GR data. (C) $2 \pi$-MTM power spectrum of the La2004 astronomical variations (Laskar et al., 2004) in ETP format (Eccentricity, Tilt, Precession, e.g., Imbrie et al., 1984, pp. 296297) for the interval from 31.065 to $34.710 \mathrm{Ma}$, roughly corresponding to the studied time interval I1. All spectral periods are expressed in kiloyears.
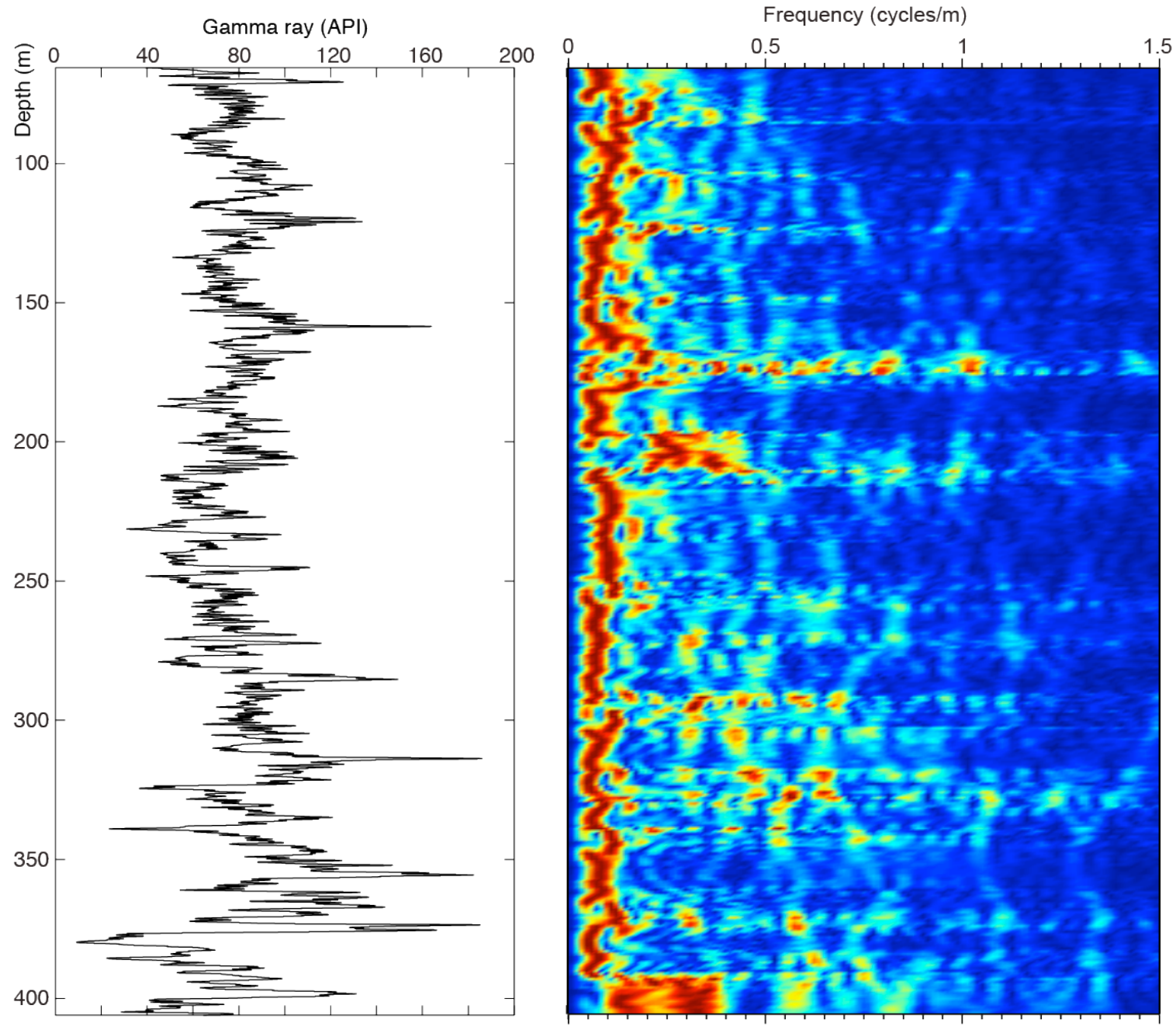

Figure S8. Evolutive harmonic analysis (EHA) of the untuned raw gamma-ray variations for the interval from 65.5 to $406 \mathrm{~m}$. Spectral line indicates the $\sim 20 \mathrm{~m}$ thick cycles. EHA options: window $=20 \mathrm{~m}$, step $=0.1 \mathrm{~m}$. 


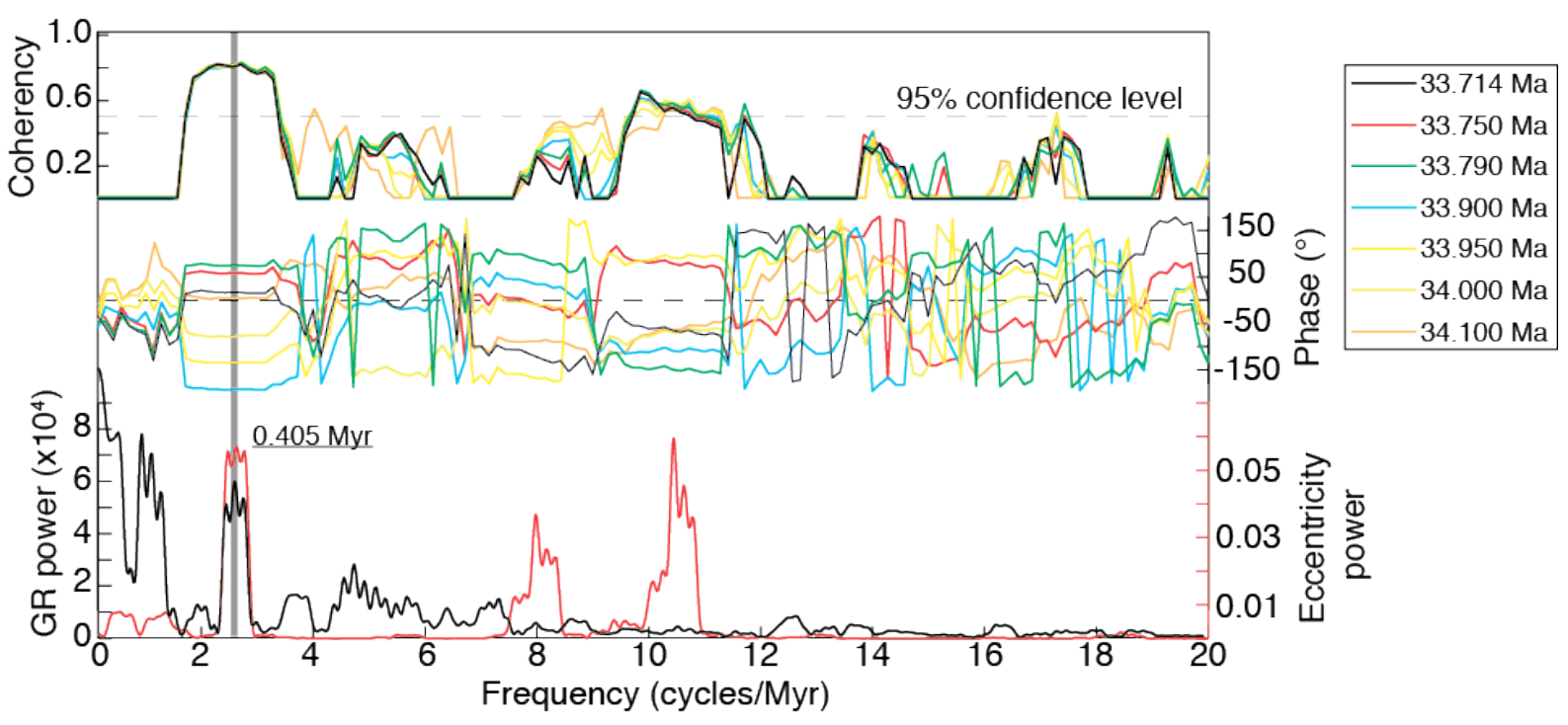

Figure S9. Coherency and cross-phase spectral analysis of the 405 kyr tuned gamma-ray data (GR) anchored at different ages of the Eocene-Oligocene boundary (tested ages and assoicated color coding in upper right panel, see Table S3 for references) versus the raw orbital eccentricity (Laskar et al., 2004). The approximate 95\% confidence level for the coherency between red noise and a narrow band signal is indicated by the grey dashed line; the zero phase line is indicated by the black dashed line. Note the high coherency and phase relationship at the $405 \mathrm{kyr}$ periodicity at the vertical grey shaded bar. 


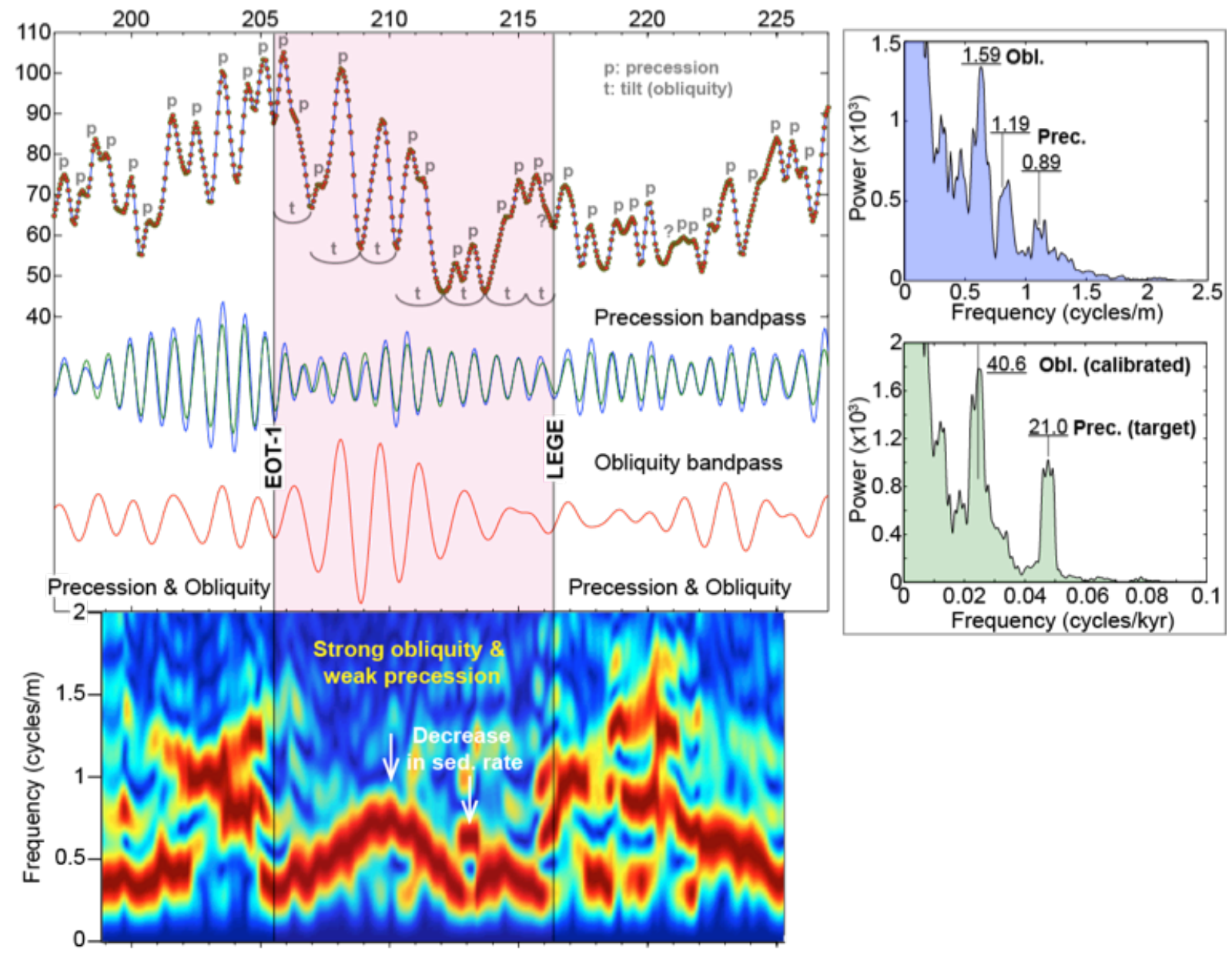

Figure S10. Evolutive harmonic analysis (EHA) of the untuned raw gamma-ray variations along with precession and obliquity bandpass filtering for the interval from 197 to $227 \mathrm{~m}$ to show the dominance of the obliquity, starting at around $216.5 \mathrm{~m}$ and ending at $195.5 \mathrm{~m}$. These two core depths are interpreted as stratigraphically equivalent to the Late Eocene Glacial Event (LEGE) and the Eocene-Oligocence Transition event 1 (EOT-1). EHA options: window $=3.5 \mathrm{~m}$, step $=0.1 \mathrm{~m}$. Left panel: 2 pi-MTM power spectra of the raw GR data (upper) and the $21 \mathrm{kyr}$ tuned GR (lower). Note the successful calibration of the obliquity peak (of $1.59 \mathrm{~m}$ ) to a period of 40.6 kyr. 


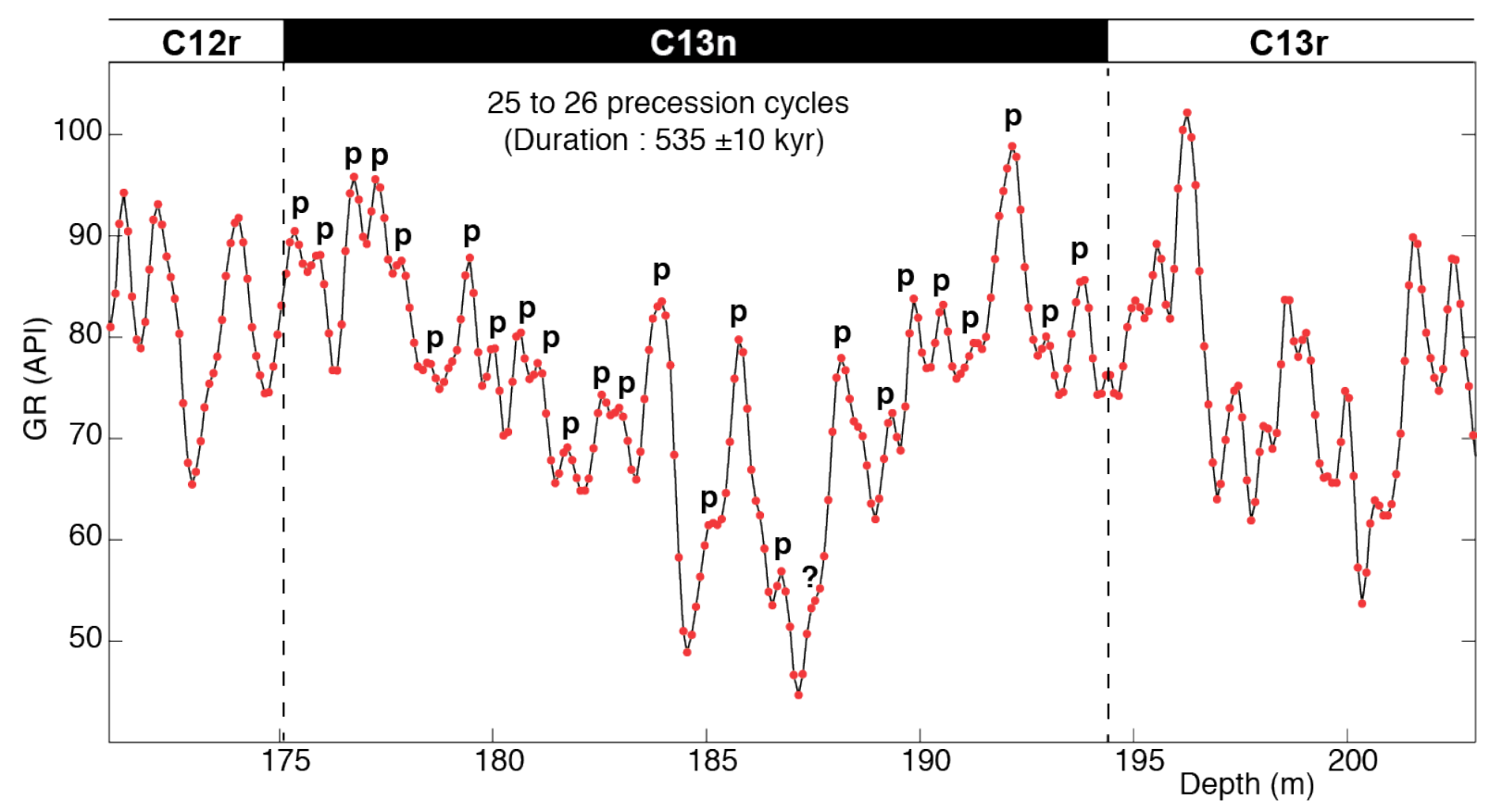

Figure S11. Example of precession cycle counting used as high-order tuning whenever the 405 kyr eccentricity cycle are seemingly complete (see 'strategy of tuning' in Section 4.3).

\begin{tabular}{|c|c|c|c|c|c|}
\hline Authors/Section & Site 1218 & Massignano & Massicore & $\begin{array}{c}\text { Monte } \\
\text { Cagnero }\end{array}$ & PEAT sites \\
\hline Coxall et al. (2005) & 33.90 & & & & \\
\hline Pälike et al. (2006) & 33.791 & & & & \\
\hline Jovane et al. (2006) & & 33.714 & & & \\
\hline van Mourik et al. (2006) & & & $\begin{array}{c}33.75 \\
\text { (Option 1) }\end{array}$ & & \\
\hline van Mourik et al. (2006) & & & $\begin{array}{c}34.1 \\
\text { (Option 2) }\end{array}$ & & \\
\hline Brown et al. (2009) & & $33.90 \pm 0.01$ & & 33.95 & \\
\hline Hyland et al. (2009) & & & & & 33.89 \\
\hline Westerhold et al. (2014) & & & & & \\
\hline
\end{tabular}

Table S4. Astronomical ages for the Eocene/Oligocene boundary used for cross-correlation. 


\section{S.4 References:}

Bauer et al. (2016) The Cenozoic history of the Armorican Massif: New insights from the deep CDB1 borehole (Rennes Basin, France). C.R. Géoscience (accepted). doi 10.1016/j.crte.2016.02.002.

Berggren W. A., Kent, D. V., Swisher, C. C., III, and Aubry, M.-P., 1995, A revised Cenozoic geochronology and chronostratigraphy: In Berggren, W. A., Kent, D. V., Aubry, M.-P. and Hardenbol, J., (eds.), Geochronology Time Scales and Global Stratigraphic Correlation, Society of Economic Paleontologists and Mineralogists Special Publication N. 54, pp. 129-212.

Brown, R.E., Koeberl, C., Montanari, A., Bice, D.M. 2009. Evidence fora change in Milankovitch forcing caused by extraterrestrial events at Massignano, Italy, Eocene-Oligocene boundary GSSP. Special Paper of the Geological Society of America, 452, 119-137.

Cahuzac, B., Poignant, A., 1997. Essai de biozonation de l'Oligo-Miocène dans les bassins européens à l'aide des grands foraminifères néritiques. Bull. Soc. Géol. Fr., 168, 155-169.

Cavelier, C., Le Calvez, Y. (1965) Présence d'Arenagula kerfornei (Allix), foraminifère 'biarritzien', a la partie terminale du Lutétien supérieur de Foulangues (Oise). Bulletin de la Société Géologique de France 7.2 (1965): 284-286.

Châteauneuf, J.J., 1980. Palynostratigraphie et paléoclimatologie de l'Eocène supérieur et de l'Oligocène du Bassin de Paris (France). Mém. BRGM, 116, 357 p.

Coxall, H.K., Wilson, P.A., Pälike, H., Lear, C.H., Backman, J., 2005. Rapid stepwise onset of Antarctic glaciation and deeper calcite compensation in the Pacific Ocean. Nature 433, 53-57.

Ghirardi, J., 2016. Impact de la transition climatique Eocène-Oligocène sur les écosystèmes continentaux, Etude du Bassin de Rennes. PhD thesis, Université d'Orléans, France.

Herron, S.L., 1991. In situ evaluation of potential source rocks by wireline logs, In: Merrill, R.K. (Ed.), Source and Migration Processes and Evaluation Techniques: AAPG Treatise of Petroleum Geology. Handbook of Petroleum Geology 1, 127-134.

Hesselbo, S.P., 1996. Spectral gamma-ray logs in relation to clay mineralogy and sequence stratigraphy, Cenozoic of the atlantic margin, offshore new jersey. In: Mountain, G.S., Miller, K.G., Blum, P., Poag, C.W., Twichell, D.C. (Eds.), Proceedings of the Ocean Drilling Program, Scientific Results 150, 411-422.

Hottinger L., Schaub, H. (1960): Zur Stufeneinteilung des Paleocaens und des Eocaens. Einführung der Stufen Ilerdien und Biarritzien. Eclogae geol. Helv. 53/1, 453-479.

Hyland, E., Murphy, B., Varela, P., Marks, K., Colwell, L., Tori, F., Monechi, S., Cleaveland, L., Brinkhuis, H., van Mourik, C.A., Coccioni, C., Bice, D., Montanari, A., 2009. Integrated stratigraphy and astrochronologic calibration of the Eocene-Oligocene transition in the Monte Cagnero section (northeastern Apennines, Italy): A potential parastratotype for the Massignano GSSP, in Koeberl, C., Montanari, A. (Eds.), The Late Eocene Earth-Hothouse, Icehouse, and Impacts. Geol. Soc. Am. Sp. Pap. 452, 303-322.

Imbrie, J., Hays, J.D., Martinson, D.G., McIntyre, A., Mix, A.C., Morley, J.J., Pisias, N.G., Prell, W.L., Shackleton, N.J., 1984. The orbital theory of Pleistocene climate: support from a revised chronology of the marine $\ddot{a}^{18} \mathrm{O}$ record, in: Berger A. et al. (Eds.), Milankovitch and climate, Understanding the response to astronomical forcing NATO. Adv. Sc. Inst. Ser. C. 126, 269-305.

Ionescu A., Alexandrescu, G. (1995) Boehlensipollis hohli in the lower Oligocene bituminous formation from Trotusului Valley (East Carpathians). Romanian Journal of Palaeontology, 76:67-72

Jovane, L., Florindo, F., Sprovieri, M., Pälike, H., 2006. Astronomic calibration of the late Eocene/early Oligocene Massignano section (central Italy). Geoch. Geophys. Geosys. 7, doi: 10.1029/2005GC001195.

King, 2016. A Revised Correlation of Tertiary Rocks in the British Isles and Adjacent Areas of New Europe. Edited by A.S. Gale \& T.L. Barry. Geological Society of London Special Report 27, 724 pp.

Köthe, A., 2003. Dinozysten-Zonierung im Tertiar Norddeutschlands. Revue de Paléobiologie 22, 895-923.

Köthe, A., 2005. Korrelation der Dinozysten-Zonen mit anderen biostratigraphisch wichtigen Mikrofossilgruppen im Tertiar Norddeutschlands. Revue de Paléobiologie 24, 697-718.

Köthe, A, 2012. A revised Cenozoic dinoflagellate cyst and calcareous nannoplankton zonation for the German sector of the southeastern North Sea Basin. Newsletters on Stratigraphy, 45, 189-220.

Köthe, A., Piesker, B., 2007. Stratigraphic distribution of Paleogene and Miocene dinocysts in Germany. Revue de Paleobiologie 26, 1-39.

Laskar, J., Robutel, P., Joutel, F., Gastineau, M., Correia, A.C.M., Levrard, B., 2004. A long-term numerical solution for the insolution quantities of the Earth. Astron. Astrophys. 428, 261-285.

Margerel, J.-P., 2009. Les foraminifères benthiques des Faluns du Miocène moyen du Blésois (Loir-et-Cher) et de Mirebeau (Vienne) dans le Centre-Ouest de la France. Geodiversitas 31 (3), 577-621.

Margerel J.-P., Bréhéret, J.-G., 1984. Révision de l'attribution stratigraphique du gi-sement de Chasné-sur-Illet (Ille-et-Vilaine) à l'aide de la faune de foraminifères et de la nannoflore calcaire. Cahiers de Micropaléontologie 1, 5-25. 
McFadden, P.L., Reid, A., 1982. Analysis of paleomagnetic inclination data. Geophys. J. R. Astr. Soc. 69, 307319.

Schuler, M. and C. Sittler. 1976. Présence d'un grain de pollen Boehlensipollis hohli W. Kr. 1962 dans les séries Tertiaires de la plaine du Forez (Massif Central). Attributions stratigraphiques nouvelles de ces terrains. Sci. Geol. Bull. 29: 91-92.

Palike, H., Norris, R.D., Herrle, J.O., Wilson, P.A., Coxall, H.K., Lear, C.H., Shackleton, N.J., Tripati, A.K., Wade, B.S., 2006. The Heartbeat of the Oligocene Climate System. Science 314, 1894-1898.

Serra-Kiel, J., Hottinger, L., Caus, E., Drabne, K., Ferrandez, C., Jauhri, A. K., Less, G., Pavlovec, R., Pignatti, J., Samso, J.-M., Schaub, H., Sirel, E., Strougo, A., Tambareau, Y., Tosquella, J., Zakrevskaya, E., 1998. Larger foraminiferal biostratigraphy of the Tethyan Paleocene and Eocene. Bull. Soc. Géol. Fr., 169, 281299.

Sittler, C, Schuler, M., 1976. Extension stratigraphique, répartition géographique et écologie de deux genres polliniques paléogènes observés en Europe occidentale: Aglaoreidia et Boehlensipollis. Bull. Soc. Bot. Fr, $122,231-254$.

Sittler, C., Monique Schuler, C. Caratini, J. J. Chateauneuf, C. Gruas-Cavagnetto, S. Jardine, M. F. Ollivier, E. Roche \& C. Tissot (1975) Extension stratigraphique, répartition géographique et écologie de deux genres polliniques paléogènes observés en Europe occidentale: Aglaoreidia et Boehlensipollis, Bulletin de la Société Botanique de France, 122:sup1, 231-245, DOI:10.1080/00378941.1975.10835657.

Van Vliet-Lanoë, B., Laurent, M., Hallégouët, B., Margerel, J.-P., Chauvel, J.- J., Michel, Y., Moguedet, G., Trautmann, F., Vauthier, S., 1998. Le Mio- Pliocène du Massif armoricain. Données nouvelles. C. R. Acad. Sci. Paris, Ser. IIa 326, 333-340.

Vandenberghe, N., Hilgen, F.J., Speijer, R.P., with contributions by Ogg, J.G., Gradstein, F.M., Hammer, O., Hollis, C.J., Hooker, J.J., 2012. The Paleogene Period. In: Gradstein, F.M., Ogg, J.G., Schmitz, M.D., Ogg, G.M. (Eds.), The Geological Time Scale 2012, vol. 2, Elsevier, pp. 855-921.

Van Mourik, C.A., Lourens, L.J., Brinkhuis, H., Pälike, H., Hilgen, F.J., Montanari, A., Coccioni, R., 2006. From greenhouse to icehouse at the Massignano Eocene-Oligocene GSSP: Implications for the cause, timing and effect of the Oi-1 glaciation, in: van Mourik, C.A. (Ed.), The Greenhouse-Icehouse Transition, A Dinoflagellate Perspective. Ph.D. thesis, Stockholm University, 327.

Westerhold, T., Röhl, U., Pälike, H., Wilkens, R., Wilson, P.A., Acton, G., 2014. Orbitally tuned timescale and astronomical forcing in the middle Eocene to early Oligocene. Clim. Past 10, 955-973. 